\title{
Brand Selection on Different Items - A Study for Investigation of Bangladeshi Young Customer Priority Level
}

Prasad RK*, Jannat F and Ali A

Department of AMT, BGMEA University of Fashion and Technology, Dhaka, Bangladesh

\begin{abstract}
Peoples mind, behavior and attitude are changed very quickly for the globalization and technology. Now a day's Bangladeshi young customers are well informed about the clothing items and they spent more time for this. This paper explores Bangladeshi young customers buying behavior when they go to purchase different fashion items liket-shirt, polo shirt, shirt and pant. Data is collected from 350 people from different area of Dhaka, Savar and Gazipur. Data is analyzed as first priority and second priority label for each fashion item. This research helps to know which brand product are got most priority for a particular item, which brand is doing well business in Bangladeshi fashion market etc. Many fashion maker or brand developer is helped by that to improve their fashion marketing, increasing customer demands and build a strong relationship with the customer.
\end{abstract}

Keywords: Customer buying behavior; Clothing brand; Different item; First priority; Second priority

\section{Introduction}

Today, we live in consumer based society where consumer is known as the king of the market. The behavior of the customer affects the market size, brand name, fashion etc. [1]. Consumer buying behavior has dramatically changed in the last few decades. Consumers are better informed and have more choices in purchasing. Consumer's purchase decision is dependent on many different factors for example, brand equity brand loyalty [2-4]. Time tested concepts on brand loyalty and mass marketing, are being turned on their heads as they fail to gauge the purchase decision of new generation customers [5]. Variations in customers like and dislike, the cognitive growth and motivation force them to act in various ways in purchasing clothing's products $[6,7]$. Clothing is considered to be second skin of the body and interest in clothing is higher during the whole life. Bangladeshi people are very traditional in clothing choice [6]. Domestic clothing market of Bangladesh plays a very important role for the Bangladeshi young customer as they produce choice able clothing. Bangladeshi domestic clothing market is customer orienting market. Customer orientation marketing is a contemporary marketing technique based on customer needs and wants. This technique aims at producing items and goods that people willing to buy [8]. Bangladeshi domestic clothing market mainly produces $\mathrm{t}$-shirt, polo shirt, woven shirt and denim pant for the Bangladeshi young customer. The customer everyone has a separate and elegant fashion sense which is mainly related to the clothing throughout the world. Clothing defines the personality, education, behavior and the way of thinking of the people [9]. Bangladeshi young customers are mainly dependent on different brand for different types of clothing as different brand produces quality full clothing product. Brand management holds the key in the modern apparel market [10]. Many young customer of Bangladesh like local product other than brand product as local product offers low cost to the customer. Although different brand produces almost same type of quality full clothing for the young customer but the customer has different brand choice for each type of clothing product. This paper focuses on the priority level of Bangladeshi young customer for different clothing product from different brand. The paper explores the first and second priority level of basic apparel product from 20 different brands of Bangladesh.

\section{Brand and Brand Value}

A brand, as defined by Keller, is "a product, but one that adds other dimensions that differentiate it in some way from other products designed to satisfy the same need $[6,11]$. A brand is a distinguishing name and/or symbol (such as logo, trademark, or package design) intended to identify the goods or services of either one seller or a group of sellers, and to differentiate those goods or services from those of competitors [12]. Brand values in industrial marketing are, therefore, the things which cause people to buy one company's product or service rather than another. They can be big issues - the core brand values or they can be small issues - noncore values. Brand values can relate to the products, pricing, the delivery or other aspect of service $[12,13]$.

\section{Methodology}

Research approach: The aim of this study was to investigate the Bangladeshi young customer priority level of different product from different brand. The questionnaire has been made on the basis on some different clothing item and some popular brand of Bangladesh. The questionnaire was handed out to customer in the stores of different market.

Problem analysis: This study has been carried out to identify the brand priority for $\mathrm{t}$-shirt, polo shirt, woven shirt and denim pant. It has been carried out by providing questionnaire to the target customers who are interested about clothing brand. The result of this study can be used to the brand developer of clothing item. This study also helps to the brand manufacturer to improve the quality of the existing product.

Develop questions: The questionnaire has been made by

*Corresponding author: Ripon Kumar Prasad, Department of AMT, BGMEA University of Fashion and Technology, Dhaka, Bangladesh, Tel: 88028919986; E-mail: srkprasadte10@gmail.com

Received October 20, 2016; Accepted October 24, 2016; Published October 28 2016

Citation: Prasad RK, Jannat F, Ali A (2016) Brand Selection on Different Items - A Study for Investigation of Bangladeshi Young Customer Priority Level. J Textile Sci Eng 6: 276. doi: 10.4172/2165-8064.1000276

Copyright: (c) 2016 Prasad RK, et al. This is an open-access article distributed under the terms of the Creative Commons Attribution License, which permits unrestricted use, distribution, and reproduction in any medium, provided the original author and source are credited. 
considering the target customer gender, age, location, purchase capability etc. Closed ended questions has been developed with "tick mark" option for customer, so it is not time consuming and difficult for the customer. On the questionnaire there are 20 brand names which brands are very popular in Bangladesh. There is also an option "without brand" in the questionnaire as many customers may not be interested to brand for high price.

Data collection and sampling: The data was collected from 350 young customers to know their brand priority about t-shirt, polo-shirt, woven shirt and pant. Respondents were aged from 18-24 and located at dwelling places such as Dhaka, Gazipur, Narayangong as brand clothing item are available at central area and near about central area. The data has been collected also from the different University Campus such as DU, JU, BUFT, AIUB, NSU, EWU etc.

Data analysis: Data analysis is conducted through the process of quantitative content analysis. The data processed through Microsoft word and excel program.

Measure: A sample size of 350 young customers taken from different market places of Dhaka city to ensure adequate items to response ratio. Among the total respondents maximum are students also including employee which contains male and female both.

Results: From the findings a fashion designing and marketing can be estimated for any t-shirt, polo shirt, woven shirt and denim pant suppliers and apparel retail brands. And from the detailed discussion of clothing materials, the outcomes can be used as a base of "product development" for t-shirt, polo shirt, woven shirt and pant. This study can also used in the new brand development process.

\section{Results and Discussions}

\section{First and second priority of brand for T-shirt purchase}

The questionnaire have 20 top brand and without brand option. Among 350 people 73 people choose easy brand as first priority for purchasing t-shirt which covered $20.68 \%$ of total respondents. On the other hand, 71 people among 350 people choose easy brand t-shirt as second priority. Easy brand offers comparatively low price product to the customer. Peoples are also interested in quality which can be seen in purchasing yellow brand t-shirt. On the other hand availability of product is one major factor for purchasing any item. Easy brand product and without brand highly available in the market so that these brand product has more priority than other brand (Figure 1).

\section{First and second priority of brand for polo shirt purchase}

$15.30 \%$ of total respondents choose easy brand polo shirt as first priorities where as $14.73 \%$ of total respondents choose easy brand polo shirt as second priority for purchase. Easy also offers comparatively low price than other as like $t$ shirt. Most of the people choose easy brand for the low price and great availability in the market. $13.60 \%$ and $11.05 \%$ young customers were choosing without brand polo shirt for the first and second priority respectively for the low price offering. Some of the young customers choose high price polo shirt with good quality like yellow brand (Figure 2).

\section{First and second priority of brand for woven shirt purchase}

56 respondents out of 350 respondents choose without brand woven shirt due to low price with medium to high quality fabric. $15.6 \%$ choose without brand woven shirt as first priority and $10.76 \%$ choose it as second priority. Lower amount of respondents choose Richman brand $\mathrm{t}$-shirt and polo shirt as first and second priority but in case of woven shirt no. of respondents priority level increase to Richman brand. Some of the respondent choose Easy brand woven shirt due lower price than other brand as like t-shirt and polo shirt. Respondents of yellow brand were increase for woven shirt than knit item due to high quality fabric with finer count yarn offered by yellow brand (Figure 3 ).

\section{First and second priority of brand for denim pant purchase}

In case of pant, no top class brand has the maximum percentage as first and second priority. $22.10 \%$ and $15.01 \%$ respondents choose without brand pant as first and second priority respectively. Without brand pant offers very lower price to customer for this reason respondents has more interest on without brand pant. On the other some of the respondents choose yellow, easy and Westecs brand pant although they have very high price compared to without brand (Figure 4).

From the overall discussion, it has been observed that for knit item garments respondents have more priority on easy brand. But in case of woven items respondents have more priority on without brand garments. Taste is one's own so that each respondent has separate brand choice for each item although some of customer choose same brand for all of items.

\section{Conclusion}

From the study that the authors performed and draw the conclusion that the young Bangladeshi fashion customer have different brand priority for different items which depends on many factors

\section{First and Second Priority of Polo shirt}

- First Priority $\quad$ Second Priority

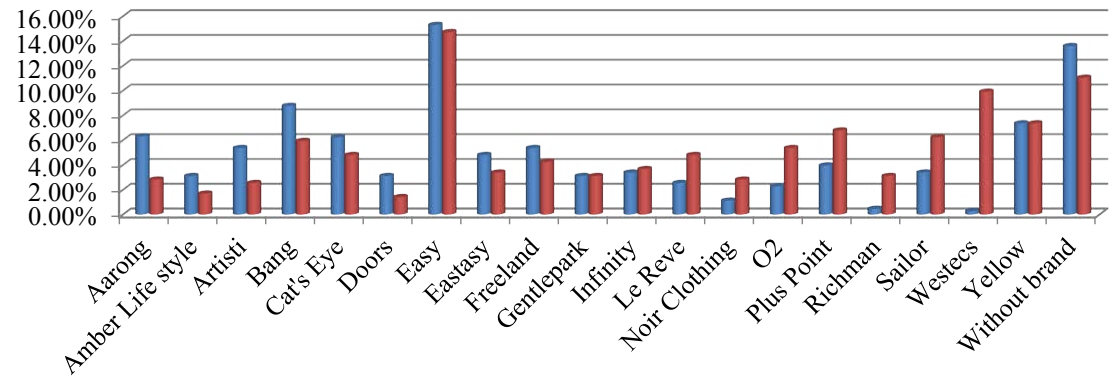

Figure 1: First and second priority of brand for T-shirt purchase. 
Citation: Prasad RK, Jannat F, Ali A (2016) Brand Selection on Different Items - A Study for Investigation of Bangladeshi Young Customer Priority Level. J Textile Sci Eng 6: 276. doi: 10.4172/2165-8064.1000276

\section{First and Second Priority of Polo shirt}

$\square$ First Priority $\quad$ Second Priority

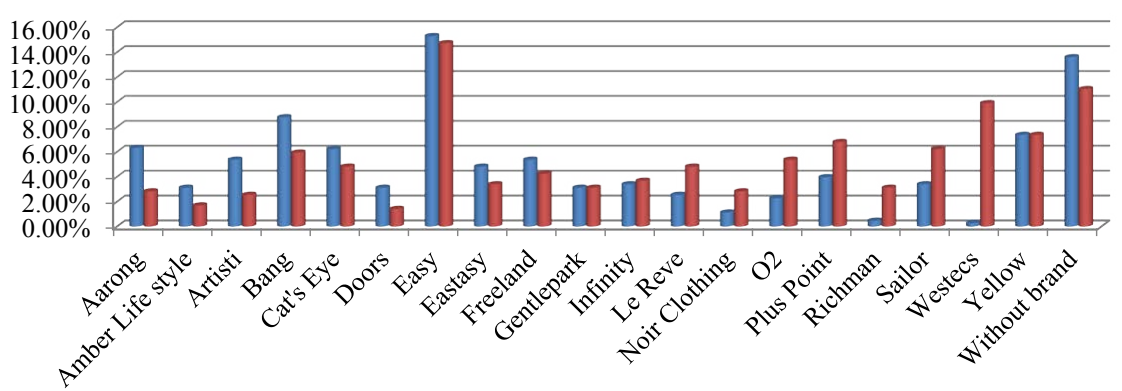

Figure 2: First and second priority of brand for polo shirt purchase.

First and Second Priority of Woven shirt

n First Priority $\quad$ Second Priority

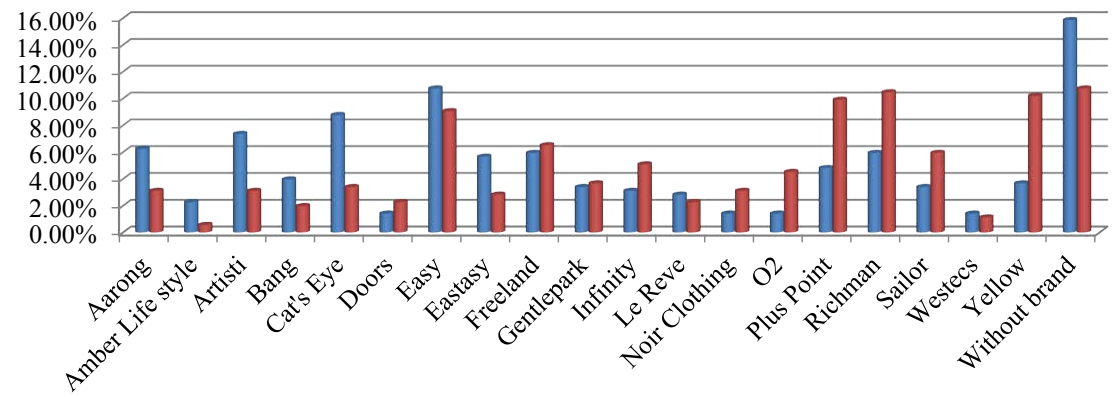

Figure 3: First and second priority of brand for woven shirt purchase.

First and Second Priority of Pant

$\square$ First Priority $\quad$ Second Priority

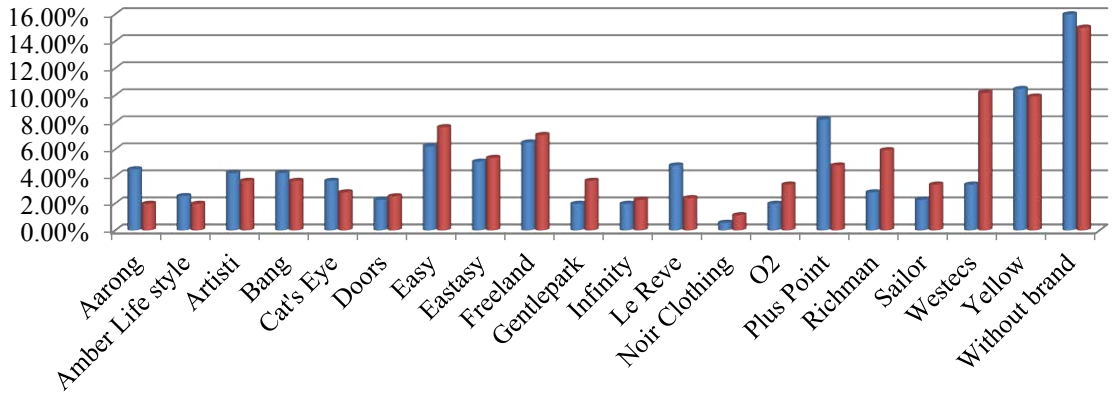

Figure 4: First and second priority of brand for pant purchase.

such as price, quality, availability, brand value etc. The results of this study also accelerate the fashion trend of the young customer where the study only shows the brand priority about the young customer perception for $\mathrm{t}$-shirt, polo shirt, shirt and pant. The results show that $20.68 \%$ of customers choose the Easy brand as their first choice in purchasing t-shirt. $12.75 \%$ of customers choose Without Brand (Local) and $10.48 \%$ of customer choose Bang brand as their first choice of purchasing t-shirt at second and third stage. On the other hand $20.11 \%$ of customer choose Easy brand as their second choice in purchasing t-shirt. In that case Yellow and Plus Point got $9.35 \%$ and $8.78 \%$ of total respondents of their second choice of purchasing t-shirt at second and third position. $15.30 \%$ of customers choose Easy brand as their first choice in purchasing polo shirt. $13.60 \%$ of customers choose Without Brand (Local) and $8.78 \%$ of customer choose Bang brand as their first choice of purchasing polo shirt at second and third position. On the other hand $14.73 \%$ of customer choose Easy brand as their second choice in purchasing polo shirt. In that case Without Brand (Local) and Yellow got $11.05 \%$ and $9.92 \%$ of total respondents of their second 
Citation: Prasad RK, Jannat F, Ali A (2016) Brand Selection on Different Items - A Study for Investigation of Bangladeshi Young Customer Priority Level. J Textile Sci Eng 6: 276. doi: 10.4172/2165-8064.1000276

choice of purchasing polo shirt at second and third position. $15.86 \%$ of customers choose Without Brand (Local) as their first choice in purchasing shirt. $10.76 \%$ of customer choose Easy brand and $8.78 \%$ of customer choose Cat's Eye brand as their first choice of purchasing shirt at second and third position. On the other hand $10.76 \%$ of customers choose Without Brand (Local) as their second choice in purchasing shirt. In that case $10.48 \%$ and $10.20 \%$ of total respondents choose Richman and Yellow brand respectively of their second choice of purchasing shirt at second and third position. $22.10 \%$ of customers choose Without Brand (Local) as their first choice in purchasing denim pant. $10.48 \%$ of customer choose Yellow brand and $8.22 \%$ of customer choose Plus Point brand as their first choice for purchasing denim pant at second and third position. On the other hand $15.01 \%$ of customers choose Without Brand (Local) as their second choice in purchasing pant. In that case $10.20 \%$ and $9.92 \%$ of total respondents choose Westecs and Yellow of their second choice of purchasing pant at second and third position.

\section{Acknowledgement}

The authors are thankful to young customers of different places who shared their buying behavior and priority level in time of purchasing different types of fashion items.

\section{References}

1. Thakur A, Lamba, B (2013) Factors Influencing Readymade Apparel Purchase in Jalandhar City. Researchers World 4: 155.

2. Knox S, Walker D (2001) Measuring and Managing Brand Loyalty. Journal of Strategic Marketing 9: 111-129.
3. Myers C (2003) Managing Brand Equity: A look at the Impact of Attributes. Journal of Product and Brand Management 12: 39-52.

4. Rahman MS (2012) Young consumer's perception on foreign made fast moving consumer goods: the role of religiosity, spirituality and animosity. International Journal of Business and Management Science 5: 103.

5. Babu MG, Vani G, Panchanatham N (2010) Consumer Buying Behaviour.

6. Islam MM, Islam MM, Azim AYMA, Anwar MR, Uddin MM (2014) Customer perceptions in buying decision towards branded Bangladeshi local appare products. European Scientific Journal.

7. Lalitha A, Ravikumar J, Padmavali K (2008) Brand preference of Men Wear. Indian Journal of Marketing 38: 33-36.

8. Sanad RA (2016) Consumer Attitude and Purchase Decision towards Textiles and Apparel Products. World Journal of Textile Engineering and Technology 2: $16-30$.

9. Rajput N, Kesharwani S, Khanna A (2012) Consumers' attitude towards branded apparels: gender perspective. International Journal of Marketing Studie 4: 111

10. Pandian MSK, Varathani SN, Keerthivasan V (2012) An Empirical study on consumer perception towards branded shirts in Trichy City. International Journal of Marketing, Financial Services and Management Research 20

11. Biplab SB (1998) Hand Book of Marketing Management, Himalaya Publishing House.

12. Aaker DA (1991) Managing Brand Equity. New York: The Free Press.

13. Prasad RK, Arifuzzaman M (2016) Buying Behavior of Young Customers in Bangladesh-A Movement towards Investigation of Their Fashion Attributes. International Journal of Textile Science 5: 19-24. 